\title{
nature
}

\section{A nut to crack a sledgehammer}

Antidoping scientists are failing in their efforts to rid sport of performance-enhancing drugs. But there are no inherent technical obstacles - the problem is simply one of resources.

$\mathrm{T}$ wo years ago, Juan Antonio Samaranch, president of the International Olympic Committee (IOC), provoked a storm by suggesting in an interview that athletes should be allowed to take performance-enhancing drugs, provided the substances are not damaging to health. Samaranch subsequently claimed to have been misinterpreted, and the idea was swiftly forgotten.

On the eve of the Sydney Olympics, and with the media buzzing with suggestions that drug use in sport is rife, it is tempting to revisit this idea. If the dope testers cannot keep pace with the drug abusers, surely it would be best to concentrate on protecting athletes from themselves, rather than chasing the elusive ideal of drug-free competition? But although despair about the failure of current doping control measures is valid (see page 124), this logic is based on two erroneous assumptions.

The first is that science will never be able to solve the problem. In fact, the scientific challenges are not especially large - the main obstacle is the sums of money required to develop and validate the necessary tests. The second is that there is any meaningful distinction between 'performance-enhancing' and 'harmful' drugs — the vast majority of substances on the IOC's banned list are, to a greater or lesser degree, potentially harmful to health.

In any case, athletes seem no more likely to comply with a system that is nominally there to protect their health than with one that seeks to disqualify the 'cheats'. In a 1995 survey of élite US athletes, virtually all respondents said they would take a banned substance if they were certain not to be caught and certain to win. More than half said they would do the same if they were certain to win every competition for five years and subsequently die from the drug's side effects.

Given athletes' will to win, apparently at any personal cost, the real problem is that the scientists appointed by sports federations to develop antidoping tests and put them into action are being given a nut to crack a sledgehammer. The solution is not to back off from testing, or to change the criteria by which drugs are put on the banned list, but to encourage sports governing bodies to open their coffers wide enough to give the scientists the resources they need to do the job effectively.

A report published last week by the US National Commission on Sports and Substance Abuse suggests that a five-year research programme of US $\$ 100$ million would put the antidoping scientists back on level terms. The report also criticizes the IOC for failing to promote the development of more new tests, and argues that only a truly independent international body - one that does not depend for its existence on the financial success of the Olympic Games - would have the necessary distance from commercial pressures to ensure that a true drug-free policy is enforced.

In theory, such a body has already been created, at least in name. The World Anti-Doping Agency (WADA), based in Lausanne, Switzerland, was established in January. For its first two years, WADA will be funded by the IOC, but thereafter should receive $50 \%$ of its money from governments. It will take over Olympic doping control after Sydney, and also work with national sporting federations to oversee out-of-competition testing.

For WADA to make any difference, it must demonstrate its independence from the IOC, gain many more affiliate countries than the handful that have so far signed up, and convince them to fund an antidoping budget that approaches the figure suggested by the US National Commission on Sports and Substance Abuse. If it fails to do this, many athletes will continue to make the choice between doping and not winning.

\section{Time for a truce?}

\section{Public bickering over a controversial theory on the origins of AIDS is generating more heat than light.}

$\mathrm{B}$ y underlining the potential dangers involved in creating novel pathways by which pathogens can pass from animals to humans, the author Edward Hooper has performed a useful service. In his book The River, Hooper argues that the origins of HIV lie in a contaminated polio vaccine produced from chimpanzee tissue and used in Africa in the late 1950s. Even those who dismiss this argument will accept that there has been complacency about the ease with which pathogens can cross the species barrier. The history of BSE in Britain perhaps provides the most graphic example - and as virologists weigh the potential dangers posed by xenotransplantation, Hooper has delivered a timely warning.

But in pursuing his hypothesis with such zeal, Hooper risks undermining the effectiveness of this message. This week's meeting at the Royal Society in London, at which Hooper confronted those he criticizes in his book, was at times an unedifying spectacle (see page 117). There seems no prospect of a resolution of the conflict between Hooper's insistence that he has verbal evidence that chimpanzee kidneys were sent to the Wistar Institute in Philadelphia and university research centres in Belgium, and the outright denials of the researchers involved. Similarly entrenched positions greeted the news that samples of Wistar vaccines dating from the period were produced using monkey, not chimp, tissue, and are not contaminated with the virus. The accused scientists are overoptimistic in hoping that these results will "put to rest" Hooper's accusations — the samples available today represent only some of the many batches of vaccines made. But Hooper will win few plaudits by dismissing the results as "irrelevant".

The question of whether the AIDS epidemic was triggered by contaminated polio vaccine is a legitimate one — but for reasons of public interest, not 'scientific' truth. Hooper's hypothesis cannot be tested experimentally. Given this, any inquiry into the hypothesis needs to be assessed in terms of its own social costs and benefits. If the costs - for example, in undermining public confidence in vaccines, or in distracting AIDS researchers from more pressing tasks - are too high, and the benefits questionable, it may be time for a truce. 